REIFSCHNEIDER, FJB; LOPES, CA; RIBEIRO, CSC. 2016. Continuity, focus and impact: a commented historical perspective on Embrapa Vegetables' extended Capsicum breeding program. Horticultura Brasileira 34: 155-160 DOI - http://dx.doi.org/10.1590/S0102-053620160000200002

\title{
Continuity, focus and impact: a commented historical perspective on Embrapa Vegetables' extended Capsicum breeding program
}

\author{
Francisco JB Reifschneider'; Carlos A Lopes²; Cláudia SC Ribeiro² \\ ${ }^{1}$ Embrapa/Secretaria de Relações Internacionais, Brasília-DF, Brasil; francisco.reifschneider@embrapa.br; ${ }^{2}$ Embrapa Hortaliças, Brasília- \\ DF, Brasil; carlos.lopes@embrapa.br; claudia.ribeiro@embrapa.br
}

\begin{abstract}
The article describes the origin, development and main results of Embrapa Vegetables' Capsicum breeding program, a continuous activity for more than three decades. The article points out and highlights how partnerships, both in Brazil and abroad, both with the public and the private sectors, were vital to the success of the program. The article also glosses over the development of the Capsicum germplasm bank and its importance to the breeding program, concluding with a set of faced challenges and lessons learned which might be of interest to other similar programs.
\end{abstract}

Keywords: Capsicum annuum, C. baccatum, C. frutescens, C. chinense, hot pepper, sweet pepper, chili pepper, genetics.

\section{RESUMO}

Continuidade, foco e impacto: uma perspectiva histórica comentada do programa estendido de melhoramento de Capsicum na Embrapa Hortaliças

$\mathrm{O}$ artigo descreve a origem, desenvolvimento e principais resultados do programa de melhoramento de Capsicum da Embrapa Hortaliças, uma ação contínua com mais de três décadas. O artigo indica e ressalta como as parcerias, tanto nacionais, quanto internacionais, tanto com agentes públicos, como com agentes privados, foram essenciais para o sucesso do programa. $\mathrm{O}$ artigo discorre ainda sobre a formação do banco de germoplasma de Capsicum e sua importância para o programa de melhoramento, concluindo com uma série de desafios enfrentados e lições aprendidas, que poderão servir como pontos de reflexão para outros programas similares.

Palavras-chave: Capsicum annuum, C. baccatum, C. frutescens, $C$. chinense, pimenta, pimentão, genética.

\section{(Recebido para publicação em 20 de dezembro de 2015; aceito em 21 de março de 2016)}

(Received on December 20, 2015; accepted on March 2016)

\section{THE ORIGIN}

A fter more than three decades of work, what actually happened and the perception of what happened merge into the same reality for those who describe it. It is impossible to specify the exact origin of a breeding program that reaches 40 years: there were certainly many factors, both personal (who is not attracted by the variability of peppers?) and professional. But, in fact, the motto of those who worked and still work in the program leadership follows a modest phrase from the great Fernando Pessoa:

"Put all you are at the least you do" ("Põe quanto és no mínimo que fazes").

In the early 1980s, the Unit for Research Implementation at State Level - UEPAE of Brasilia, under the leadership of Flavio AA Couto, head and mentor, started taking its first steps to move from a state to a national mandate as another national center of the Brazilian Agricultural Research Corporation (Embrapa), focusing on vegetable crops. Technical teams were trained, while the infrastructure was being prepared. Young and enthusiastic researchers, as the first two authors, at that point recently postgraduates and charmed by genetic disease resistance, received clear guidance to develop their work focusing in developing solutions to relevant problems of the Brazilian agriculture. They saw in this mission the means to return to the country the support they received in their education and qualification.

At that time, a disease caused by then a fungus, now an oomycete, Phytophthora capsici, pepper blight, caused great losses in several regions of Brazil, particularly in the states of Minas Gerais and Rio de Janeiro. Additionally, the pathogen was also identified as the causal agent of significant damage in squash fields in the Federal District and surroundings, in the states of Goiás and Minas Gerais.

These two basic elements - a new institution and an important disease, more than any others, worked as catalysts for the implementation of the embryo of the Capsicum breeding program. Due to the relevance of this disease, surveys on losses and on the pathogen were carried out to advance the knowledge on pathogen variability, compatibility groups (A1 and A2) and other important parameters of the hostpathogen interaction.

Concurrently, chemical control tests using new products available at the time, as metalaxyl, fosetyl, Calda Cunesa (provisional license for use on lettuce and tomato released in 1981), as well 
as more traditional ones, as mancozeb, were initiated. Additional trials were carried out aiming at studying the effectiveness of agronomic practices, such as earthing up and control of the irrigation water, in addition to chemical control, on disease management.

The progress of the work, targeting fundamentally the pathosystem (bell pepper x pepper blight), confirmed the relevance of the disease, stressing the complexity that the pathogen variability lends to it. Additionally, the initiative revealed that there were other pathogens also causing significant losses, as the Tomato Spotted Wilt Virus in chili pepper, and pointed to the need for a holistic breeding program in Capsicum spp. In Brazil, in addition to sweet and hot peppers of the species $C$. annuum; C. frutescens (Malagueta pepper), $C$. chinense (Bode and Murupi peppers) and $C$. baccatum (Dedo-de-moça pepper) were and still are planted.

It is worth mentioning that several Capsicum breeding efforts, both in Brazil and in several countries, particularly in Argentina, France and the USA, further stimulated the spirit of a healthy and positive competition. In Brazil, there were the bracing examples of Hiroshi Nagai, at the Agronomic Institute of Campinas (IAC), and Vicente WD Casali and team, at the Federal University of Viçosa (UFV), among others.

The elements of a holistic program were met: relevant technical problems challenging the productive sector of an important genus for the Brazilian horticulture; motivated, trained and expanding multidisciplinary teams; institutional encouragement and support; freedom of operate and will to face challenges. Thus, the program was born.

The germplasm collection as the basis: yesterday, today and always

The first results to come out from the surveys in the main producing areas pointed to the complex nature of the problem and to the need to focus on the development of genotypes with resistance to the major diseases caused by oomycetes (Phytophthora blight), bacteria (bacterial spot and wilt) and viruses (tomato spotted wilt), as part of integrated crop management. The addition of a young, well-trained researcher to the nascent team, the plant breeder Paulo T Della Vecchia, brought additional strength in genetics to breeding program (Figure 1).

The introduction of Capsicum germplasm, via collection and exchange, had a prominent position in the program. After all, without variability, it was obvious that it would not be possible to advance. Thus, germplasm evaluation to identify sources of resistance to major diseases became a task for all, with many interns and students working with $P$. capsici. Activities were expanded to also cover also resistance to viruses (TSWV) and to bacterial diseases (Xanthomonas vesicatoria, currently the Xanthomonas complex) and Ralstonia solanacearum (currently, the Ralstonia complex), and many additional students and researchers (consultants) joined the team. The work of Martien Beek, now back in Wageningen, Netherlands, collecting $C$. baccatum and studying virus resistance; as well as Jean M. Poulos (Cornell University, 1990), who developed the first Ph.D. thesis within the program deserves to be highlighted. It is interesting to mention that some of the first Capsicum genotypes of the germplasm bank (among the top three in the world, along with the ARS/USDA and AVRDC/World Vegetable Center), now with more than 4,000 accessions, were given by fellow researcher Josias C. Faria to the first author, while still in graduate studies in USA, working with corn in the late 1970's. Quite possibly, already a clue of the personal interest in Capsicum!

The program always invested heavily in the enrichment of its germplasm bank (Carvalho et al., 1999) and got the support of several institutions for that. Students and researchers had a leading role in enriching the bank, contributing with several accessions introduced from other banks in Brazil and abroad, as well as with new accessions collected in farms, fairs and markets. The arrival of Luciano Bianchetti and Sabrina Carvalho, experts in germplasm collection, characterization and conservation, gave a great impetus to actions strengthening both the Capsicum bank and its use in breeding. Invaluable collecting expeditions were carried out in the Atlantic Rainy Forest and in the states of Maranhão, Acre and Amazonas, the latter with the decisive and fundamental support of the Brazilian Army (Figure 2) through the General Eduardo Villas Boas, then the Amazon Military Command, currently Brazilian Army Commander General.

As new accessions were collected, new species were being discovered (Barboza \& Bianchetti, 2005), and the hard work of genotype characterization went on, producing essential information for the breeding. Currently, more than 50 morphological descriptors, internationally accepted, are used for characterization in our bank (Carvalho et al., 2003). The use breeders made of this comprehensive information allowed for the development and release of new cultivars in a short time. The morphological characterization, carried out in 100 to 200 genotypes per year, was, whenever possible, complemented by agronomic and biochemical evaluation for specific groups and characteristics of interest, such as pungency (capsaicin content), vitamin $\mathrm{C}$ content - with a pepper accession of the habanero group reaching $129 \mathrm{mg} / 100 \mathrm{~g}$ (Teodoro et al., 2013) - and even volatiles, assessed in elite lines and cultivars released by the program due to the importance of aroma in $C$. chinense peppers, known as scent peppers (Garruti et al., 2013). Pungency is unquestionably a characteristic of great appeal and importance for consumers, and it is also quite variable. There are bell peppers and sweet chilies ranging from 0 SHU (Scoville heat units) to extremely hot habanero peppers exceeding 500,000 SHU. As a reference, a very hot Malagueta chili pepper has 150,000 SHU.

The Capsicum germplasm bank of Embrapa is presently recognized as reference for germplasm collections, along with the rice, beans and grape germplasm banks, among a few others. In the Capsicum bank, we even introduced a barcode system to manage routine actions and control seed stocks (Carvalho et al., 2013). 


\section{A holistic program - from germplasm collection to the private sector}

As time went by, both priorities and the team ripened, and the need to have a sustainable breeding program, capable of meeting demands in the short, medium and long term, became evident. On the other hand, we were also concerned with providing innovations, offering new products of interest to the production chain, as well as new cultivars. The program strategy was progressively consolidating, gradually establishing a balance in which $80 \%$ of the efforts should be concentrated in meeting national demands, while the remaining $20 \%$ should be used in exploring new opportunities, taking higher risks. Thus, risk management got into the program, although it was probably not identified as such in the beginning. The financial architecture implemented took and still takes into account the intrinsically disastrous variability (and escalating bureaucracy) of public funding based on a single source, Embrapa. Therefore, the National Council for Scientific and Technological Development (CNPq) and the private sector, particularly Fuchs Agro Brazil Ltda. and Sakura Nakaya Alimentos Ltda., were important historical actors on this architecture, along with smaller, international research for development projects, particularly those supported by the Agricultural Innovation Marketplace (www.mktplace.org) since 2013, having Cláudia Ribeiro as coleader.

Two strategic decisions taken by the program coordination had significant impact: first, the regular meetings held by the coordinators of the projects kept alive the flame of collaboration, especially because in those meetings there were always reports of relevant results. There were also internal demands for more and better results. The program also benefited from external monitoring and evaluation, which contributed to its improvement; the second, the decision to focus the program on hot peppers, due to the Brazilian diversity on Capsicum and also to the fact that the private sector was focused primarily on the development of $C$. annuum sweet (and in a few cases, hot) pepper hybrids, leaving a large gap in the breeding of hot peppers and other Capsicum species.

The basic pillars for the proper pace of the program were also established. The program always counted on actions of basic and applied research, developed in multi-institutional coordination in Brazil and abroad, with the contribution of researchers, professors and technical, undergraduate and graduate (master's, doctoral and $\mathrm{Ph}$.D.) students. Partners in the academy included the University of Brasília (UnB), Cornell University, New Mexico State University, Wageningen University, the Agriculture College Luiz de Queiroz from University of São Paulo (USP-ESALQ), the State University of Northern Rio de Janeiro (UENF), the Federal Rural University of Rio de Janeiro (UFRRJ) and the Federal Institute of Goiás - Campus Ceres, among others. As far as research in concerned, there were several national partners, and within these four Embrapa units deserve special recognition: Genetic Resources and Biotechnology, Food Technology, Temperate Agriculture and Products and Markets.

The program made two big leaps at the beginning of the new millennium: the organization of Capsicum Agribusiness National Meetings (Figure 3), the first in 2004, led by Claudia Ribeiro and Sabrina Carvalho (in 2011, the IV Meeting took place in Monte Carmelo, state of Minas Gerais, with a strong and exemplary support from the municipality); the second, benefiting from the progress on information and communication technology, the setting up in 2007 of an online community on the Google Groups platform - Sweet and Hot Peppers' Agribusiness - for information exchange among those working with peppers, concentrating on farmers and processing companies. The community is still moderated by the first author and presently counts with 400 members, mainly from the private sector in Brazil. Additionally, in 1998, the first two authors registered the Capsicum Research Group at the CNPq Lattes Platform (http://lattes. cnpq.br/web/dgp), which continues to date and contains information on human resources (researchers, students and technicians), research themes in progress, knowledge fields, applied sectors involved, scientific, technological and artistic production and partnerships between groups and institutions. The group is currently led by F. Reifschneider and C. Ribeiro.

The partnerships established by means of large multi-year projects, supported by Prodetab (Gonçalves, 2001), Fuchs Agro Brazil Ltda., Sakura Nakaya Alimentos Ltda. and CNPq, were essential for the significant advances made in the Capsicum-researched, as well as quantity, quality and impact of results. Within the allowed bureaucratic limits imposed to Embrapa, the program succeeded to be flexible, meeting demands from the private sector, but keeping the deliverables as public goods. Thus, two released cultivars, BRS Sarakura and BRS Garça, were and still are of exclusive use of the private partner for a contractual limited time, while other cultivars have been licensed for seed production and sale by the companies that expressed interest on them, as it is the case of cultivars BRS Moema, BRS Mari and BRS Seriema.

It is important to stress that the actions taken towards cultivar registration and protection, satisfying the complex Brazilian regulatory legislation, were essential for partnering and celebrating contracts with the private sector. Nevertheless, it represented a great effort for the program due to the extension, slow pace and complexity of the processes (Carvalho et al., 2009). The first two Capsicum cultivars protected in Brazil were BRS Garça and BRS Sarakura in 2010 (http:// extranet.agricultura.gov.br/php/snpc/ cultivarweb/cultivares_protegidas. php?).

More specific formal and informal partnerships with small companies like Cerrado Goiano Produtos Alimentícios, as well as with numerous farmers, farmer associations and extension agent groups, were equally important. The continuity experienced in the program coordination, with one of the three coauthors taking the leadership of each of the major projects was (and still is) essential to the endurance, stability and perseverance of the program in these almost four decades. But, always 


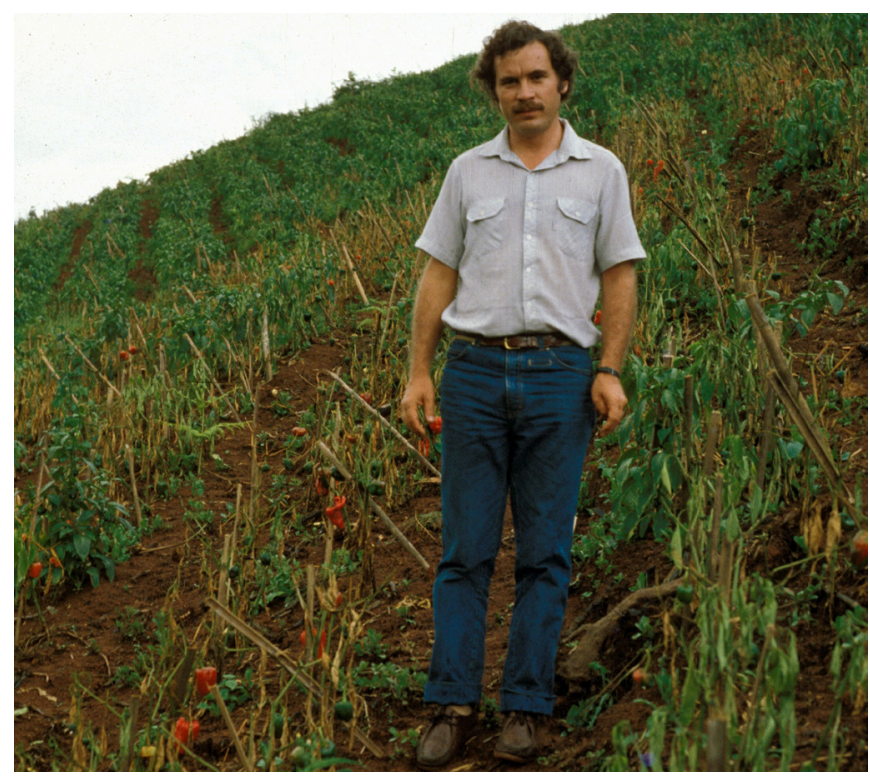

Figure 1. Paulo Della Vecchia at a field highly infected by Phytophthora in the state of Rio de Janeiro, 1982.

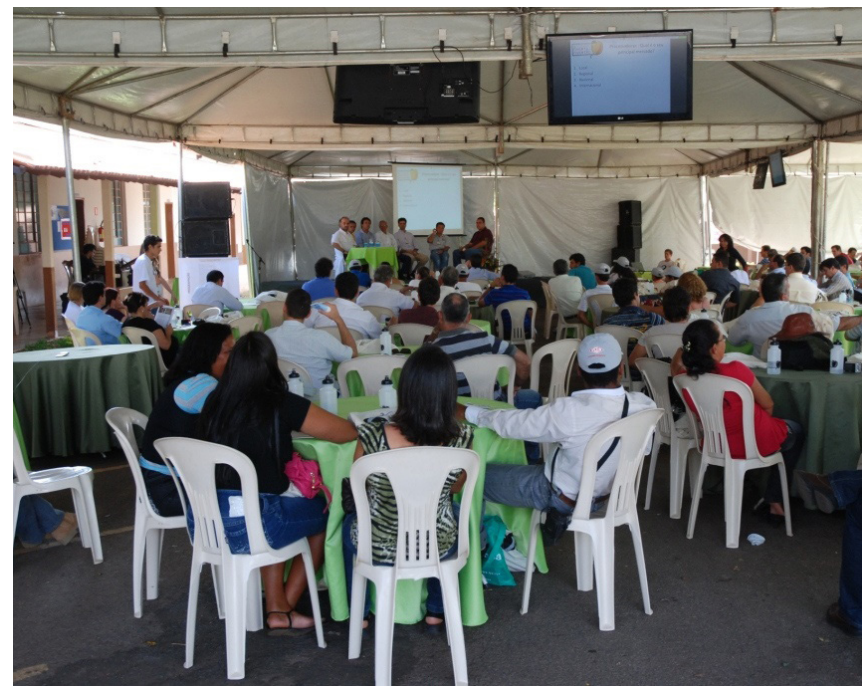

Figure 3. IV National Meeting of the Capsicum Agribusiness, in Monte Carmelo, state of Minas Gerais.

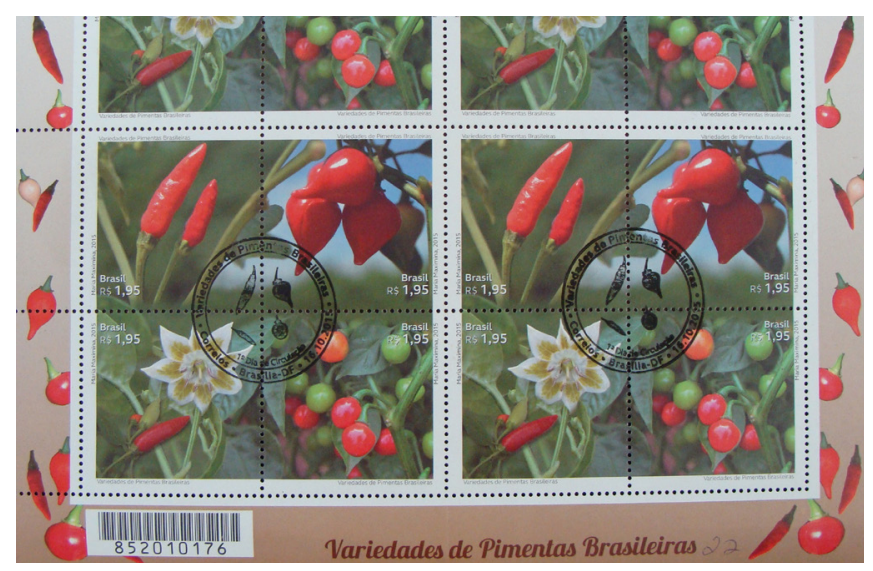

Figure 5. Postal stamps issue in 2015 by the Brazilian Post and Telegraph Company to honor cultivars BRS Moema, BRS Seriema and BRS Mari released by the program.

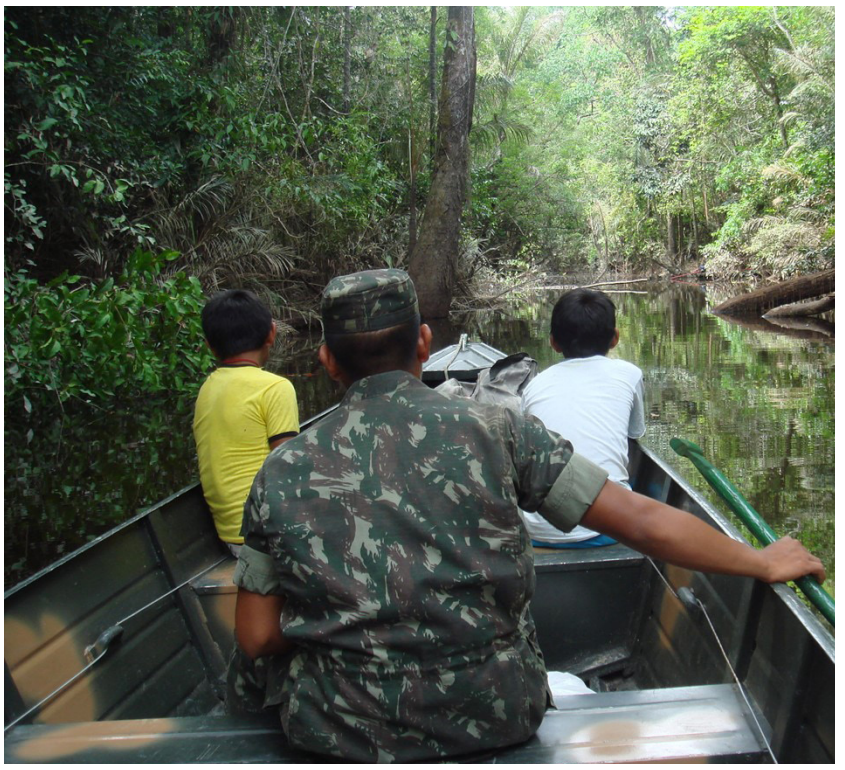

Figure 2. Collecting expedition at São Gabriel da Cacoeira region, state of Amazonas, with the support of the Brazilian army.

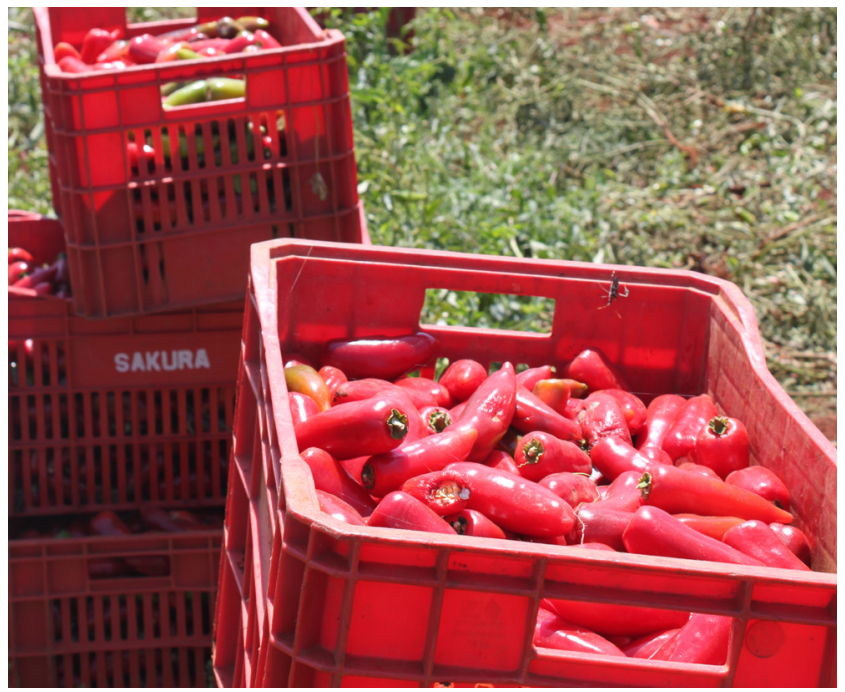

Figure 4. Harvest of cultivar BRS Sarakura in Catalão region, state of Goiás, 2015.

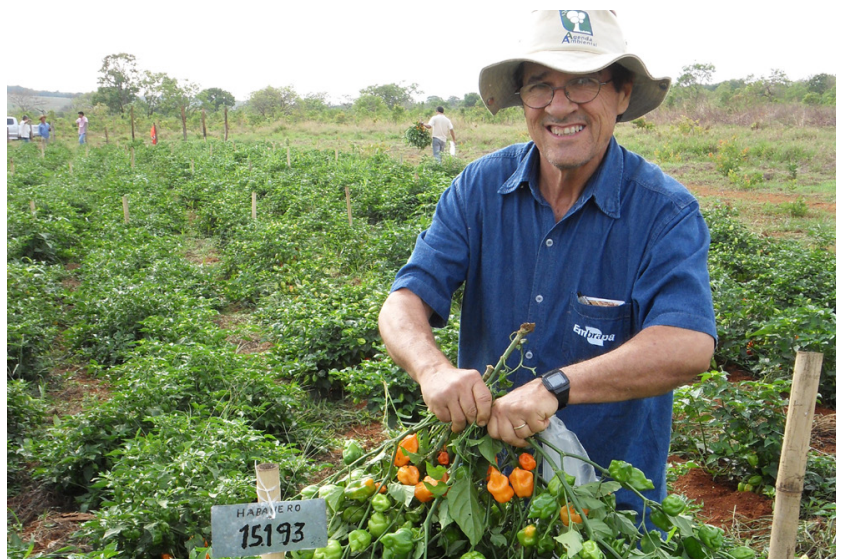

Figure 6. The program agricultural technician, Athayde L. Garcia, in Catalão, state of Goiás, with a selected plant from the lineage that later would originate one of our released cultivars. 
continuity without continuismo!

\section{RESULTS AND IMPACTS}

The results achieved so far within the program are countless and can be broadly grouped into seven categories, as follows (for each category, mention is made to only one or two examples, not necessarily the latest. Additional results can be easily found through the web!).

a. New Methodologies: more efficient methods for pathogen inoculation were developed, allowing the evaluation of multiple diseases simultaneously (Costa \& Reifschneider, 1988);

b. New lineages, hybrids and populations: lines with high levels of resistance were identified or developed (Figure 4). Some of them are used as international standard, like CNPH 703 (Poulos et al., 1992) renamed to PBC137 by the AVRDC, current World Vegetable Center; sweet pepper rootstock hybrid with multiple resistance to various pathogens; base populations for the habanero and Malagueta pepper groups (Nass et al., 2015);

c. New Cultivars: sweet pepper cultivars (Tico, developed for the Brazilian Northeast), sweet paprika (hybrid BRS Brasilândia), as well as several cultivars of sweet (BRS Moema) and hot peppers, such as BRS Garça, BRS Mari, BRS Sarakura, BRS Seriema, BRS Nandaia and BRS Juruti (Ribeiro et al., 2015);

\section{d. Technical and Scientific} Publications: dozens of scientific articles as well as book chapters (Reifschneider et al., 2015) were published in Brazil and abroad, as well as technical circulars, newsletters and similar, publications, covering various aspects of interest to the program, from historical (Reifschneider et al., 2009) to evolutionary issues, with morphological and molecular studies (Carvalho et al., 2014, 2015);

e. Books: three books (Reifschneider,
2000; Lopes \& Avila, 2003; Ribeiro et al., 2008), the first books on Capsicum written in Portuguese, were published by the program's researchers. One of the books was included along with the commemorative publications for the $500^{\text {th }}$ anniversary of the discovery of Brazil. It is worth noting that the book released in 2000 won of the prestigious Jabuti Award, while the one released in 2008 was granted the $11^{\text {th }}$ Jorge Salim Award;

\section{f. Talent Development} and Multidisciplinary Team Consolidation: with more than two dozen B.Sc., M.Sc., D.Sc. and Ph.D. thesis completed on different themes of interest to the program and with students advised or co-advised by its researchers, a major if not the main long-term result was the strengthening and/or development of professional talents, some currently abroad, as Jean Poulos and Caroline Wagner, and the consolidation of a multidisciplinary and multi-institutional team;

g. Awards: in addition to the awards granted to the publications, one of the program's project was used as a model in Embrapa and its team was honored with the National Award of Teams, in the Creativity category in 2004;

h. Postal Stamps: acknowledging the work carried out and their popularity and attractiveness, three of the cultivars released by the program were honored by the Brazilian Post and Office (Correios) as stamps issued in 2015 (Figure 5). After the actors of the program are gone, the stamps will perpetuate the efforts of their creation.

The main breeding impact per se is that of cultivar BRS Sarakura, which accounts for over $50 \%$ of all pepper sauce produced in Brazil (Figure 6). The long-term impact with greater sustainability, is certainly the group of talented young people who have contributed the program.

\section{CHALLENGES}

Many challenges were faced along the way, some very successfully, others not so much. But it is clear that challenges will continue popping up, with even greater complexity. Finding the right niche for public research on Capsicum in a period of big changes in the Brazilian agribusiness, with fewer and stronger economic agents in increasingly empty fields, is not trivial. Mounting legal and bureaucratic complexity, with ties and knots for innovation, anti-development ideologies, and fads (who do not remember that biotechnology would solve all problems of agriculture and most of the resources were directed to it?) will make the strategic challenges of the past seem like simple and easy tasks.

To change and adapt constantly; to reinvent on a daily basis, with continuity, but without continuismo; to react to the market signals, but also leaving an open door to innovation, with minimum institutional support; to ensure that leadership and team's optimism and enthusiasm endure, in an increasingly competitive system, are the big challenges of a research program such as the Capsicum breeding, embedded in a public institution.

\section{LESSONS LEARNED}

There are possibly two sets of lessons learned during those decades of organization and implementation of a program that started with a focus on breeding, but turned out to be much broader:

a. Institutional Lessons: focus on the solution of real problems of the production and processing chain, pursuit of innovation and significant partnerships, preservation of a flexible fund basket, development and delivering of relevant and impacting results, permanent concern with productivity metrics, persistence, and leadership at Nelson Mandela's way ("It is better to lead from behind and to put others in front, especially when you celebrate victory, when nice things occur. You take the front line when there is danger. Then people will appreciate your leadership").

b. Personal Lessons: to have 
an ideal, not to fear challenges, to constantly stay outside of the "comfort zone", to think outside the box; to believe in the team, fostering talents, to value partners and partnerships, to persevere, to be a cautiously optimistic, and to believe in dreams.

To believe in a better Brazil for everyone.

\section{REFERENCES}

BARBOZA, GE; BIANCHETTI, LB. 2005. Three new species of Capsicum (Solanaceae) and a key to the wild species from Brazil. Systematic Botany 30: 863-871.

CARVALHO, SIC; RAGASSI, CF; BIANCHETTI, LB; REIFSCHNEIDER, FJB; BUSO, GSC; FALEIRO, FG. 2014. Morphological and genetic relationships between wild and domesticated forms of peppers (Capsicum frutescens $\mathrm{L}$. and $C$. chinense Jacquin). Genetics and Molecular Research 13: 7447-7464.

CARVALHO, SIC; RAGASSI, CF; OLIVEIRA, LB; AMARAL, ZPS; FALEIRO, FG; REIFSCHNEIDER, FJB; BUSO, GSC. 2015. Transferability of microsatellite markers of Capsicum annuum $\mathrm{L}$. to $C$. frutescens $\mathrm{L}$. and C. chinense Jacq. Genetics and Molecular Research 14: 7937-7946.

CARVALHO, SIC; REIFSCHNEIDER, FJB; RIBEIRO, CSC; BIANCHETTI，LB; BUSTAMANTE, PG. 1999. Multiplicação, caracterização, conservação e documentação da coleção de germoplasma de Capsicum da Embrapa Hortaliças. Horticultura Brasileira 17: 280 .

CARVALHO, SIC; BIANCHETTI, LB; BUSTAMANTE, PG; SILVA, DB. 2003. Catálogo de Germoplasma de pimentas e pimentões (Capsicum spp.) da Embrapa Hortaliças. Embrapa Hortaliças, Documentos,
49. Brasília-DF. 49p. il.

CARVALHO, SIC; BIANCHETTI, LB; REIFSCHNEIDER, FJB. 2013. Capsicum germplasm bank maintained by Embrapa Vegetables, Brazil. In: Meeting on genetics and breeding of Capsicum and eggplant, Eucarpia, 15, 2013, Torino. Proceedings. Torinto: Università degli Studi di Torino. p. 199-204.

CARVALHO, SIC; BIANCHETTI, LB; REIFSCHNEIDER, FJB. 2009. Registro e proteção de cultivares pelo setor público: a experiência do programa de melhoramento de Capsicum da Embrapa Hortaliças. Horticultura Brasileira 27: 135-138.

COSTA, GO; REIFSCHNEIDER, FJB. 1988. Inoculação múltipla e técnicas de avaliação da reação de Capsicum a três patógenos: vírus $\mathrm{Y}$ da batata, Phytophtora capsici e Xanthomonas campestris pv. vesicatoria - uma proposta. Anais Escola Agronomia e Veterinária 18: 53-57.

GARRUTI, DS PINTO, NOF; ALVES, VCC; PENHA, MFA; TOBARUELA, EC; ARAUJO, IMS. 2013. Volatile profile and sensory quality of new varieties of Capsicum chinense pepper. Ciência Tecnologia Alimentos 33 (supl. 1): 102-108. Disponível em <http:// www.scielo.br/scielo.php? script $=$ sci arttext\&pid=S0101-20612013000500016\&ln $\mathrm{g}=$ en\&nrm $=$ iso $>$. Acessado em 16 de fevereiro de 2016. http://dx.doi.org/10.1590/S010120612013000500016.

GONÇALVES, AM. 2001. Fundos competitivos para o financiamento da pesquisa agrícola no Brasil: o caso do PRODETAB - Embrapa. disponível em: https://bibliotecadigital.fgv.br/dspace/ bitstream/handle/10438/8411/000313818. pdf? sequence $=1$ \&isAllowed $=y$

LOPES, C.A.; ÁVILA, A.C. Doenças do pimentão: diagnose e controle. Brasília, DF: Embrapa Hortaliças, 2003. 100 p.

NASS, Luciano L et al. Synthesis of a base population of Habanero pepper. Hortic. Bras., Vitoria da Conquista, v. 33, n. 4, p. 530-532, Dec. 2015 . Available from $<$ http://www.scielo.br/scielo.php?script=sci arttext\&pid $=$ S0102-05362015000400530\&ln $\mathrm{g}=\mathrm{en} \& \mathrm{nrm}=\mathrm{i}$ so $>$. access on 28 Mar. 2016. http://dx.doi.org/10.1590/S0102053620150000400021.

POULOS, JM; REIFSCHNEIDER, FJB; COFFMAN, RW. 1992. Inheritance of quantitative components of resistance to Xanthomonas campestris pv. vesicatoria in pepper line "CNPH 703". In: VIII MEETING GENETICS AND BREEDING ON CAPSICUM AND EGGPLANT. Rome. p.166-171.

REIFSCHNEIDER, FJB. (org). 2000. Capsicum: Pimentas e pimentões no Brasil. Brasília, DF: EMBRAPA Comunicação para Transferência de Tecnologia/ EMBRAPA Hortaliças. 133p.

REIFSCHNEIDER, FJB; NASS, LL; HENZ, GP. (org). 2015. Uma pitada de biodiversidade na mesa dos brasileiros. Brasília, DF: [s.n.]. 156 p. il., color. Acessado em 18 de fevereiro de 2016. Disponível em https://issuu.com/cica/ docs/uma_pitada_de_biodiversidade

REIFSCHNEIDER, FJB; HENZ, GP; RIBEIRO, CSC. 2009. Brazilian Capsicums: Early history and future prospects. Chronica Horticulturae 49: 20-21.

RIBEIRO, CSC; LOPES, CA; CARVALHO, SIC; HENZ, GP; REIFSCHNEIDER, FJB. (ed). 2008. Pimentas Capsicum. Brasília: Embrapa Hortaliças, 200p.

RIBEIRO CSC; SOUZA KRR; CARVALHO SIC; REIFSCHNEIDER, FJB. 2015. BRS Juruti: the first Brazilian habanero-type hot pepper cultivar. Horticultura Brasileira 33: 527-529. DOI: http://dx.doi.org/10.1590/ S0102-053620150000400020

TEODORO, AFP et al. 2013. Vitamin C content in Habanero pepper accessions (Capsicum chinense). Horticultura Brasileira 31: 5962. Acessado em mar. 2013. Disponível em $<$ http://www.scielo.br/scielo.php?script=sci arttext\&pid=S0102-05362013000100009\&ln $\mathrm{g}=\mathrm{en} \& \mathrm{nrm}=\mathrm{iso}>$. Acessado em $16 \mathrm{Fev}$. 2016. http://dx.doi.org/10.1590/S010205362013000100009 . 